\title{
Occupational Risk Assessment in School Food Services: Instruments' Construction and Internal Validation
}

\author{
Jeane dos Santos Ferreira ${ }^{1}$, Maria da Purificação Nazaré Araújo ${ }^{1}{ }^{(0)}$, Rosemary da Rocha Fonseca Barroso ${ }^{1}{ }^{(0)}$

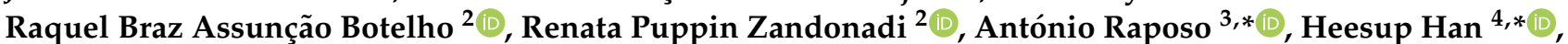 \\ Luis Araya-Castillo ${ }^{5}{ }^{\infty}$, Antonio Ariza-Montes ${ }^{6}\left(\mathbb{D}\right.$ and Rita de Cássia Coelho de Almeida Akutsu ${ }^{2}$
}

check for updates

Citation: Ferreira, J.d.S.; Araújo, M.d.P.N.; Barroso, R.d.R.F.; Botelho, R.B.A.; Zandonadi, R.P.; Raposo, A.; Han, H.; Araya-Castillo, L.;

Ariza-Montes, A.; Akutsu, R.d.C.C.d.A. Occupational Risk Assessment in School Food Services: Instruments' Construction and Internal Validation. Sustainability 2022, 14, 1728. https://doi.org/ $10.3390 /$ su14031728

Academic Editors: Emanuele Radicetti, Rana Muhammad Aadil, Ghulam Haider and Paola Tedeschi

Received: 27 December 2021

Accepted: 30 January 2022

Published: 2 February 2022

Publisher's Note: MDPI stays neutral with regard to jurisdictional claims in published maps and institutional affiliations.

Copyright: (C) 2022 by the authors. Licensee MDPI, Basel, Switzerland. This article is an open access article distributed under the terms and conditions of the Creative Commons Attribution (CC BY) license (https:// creativecommons.org/licenses/by/ $4.0 /)$.
1 School of Nutrition, Federal University of Bahia, Salvador 40110-150, Brazil; ferreira.jeane@ufba.br (J.d.S.F.); puri@ufba.br (M.d.P.N.A.); rosefonseca@ufba.br (R.d.R.F.B.)

2 Department of Nutrition, Faculty of Health Sciences, University of Brasilia, Brasilia 70910-900, Brazil; raquelbotelho@unb.br (R.B.A.B.); renatapz@unb.br (R.P.Z.); rita.akutsu@unb.br (R.d.C.C.d.A.A.)

3 CBIOS (Research Center for Biosciences and Health Technologies), Universidade Lusófona de Humanidades e Tecnologias, Campo Grande 376, 1749-024 Lisboa, Portugal

4 College of Hospitality and Tourism Management, Sejong University, Seoul 05006, Korea

5 Facultad de Economía y Negocios, Universidad Andrés Bello, Santiago 7591538, Chile; luis.araya@unab.cl

6 Social Matters Research Group, Universidad Loyola Andalucía, C/Escritor Castilla Aguayo, 4, 14004 Córdoba, Spain; ariza@uloyola.es

* Correspondence: antonio.raposo@ulusofona.pt (A.R.); heesup@sejong.ac.kr (H.H.)

\begin{abstract}
Occupational risk assessment in school food services (SFS) should include factors related to occupational hygiene, physical-functional planning, worker health, and good meal production practices. This study aimed to develop an instrument to assess occupational risk in school food services and perform content validation and semantic evaluation. The research included three steps: (i) instrument's development; (ii) content validation (Delphi); and (iii) semantic evaluation (focus group). After an extensive literature review, four instruments were developed. The Delphi was validated by the Content Validity Coefficient (CVC), with an agreement greater than $90 \%$. The semantic analysis was performed through four meetings using a focus group. After the content and semantic evaluation, there were four final instruments: Identification of Socioeconomic and Demographic Conditions of Food Handlers and Geographical Mapping of SFS (30 items); Knowledge and Attitudes in Food Hygiene Assessment (33 items); Perception of Occupational Risks (16 items); and Mapping of Occupational Risks in SFS (97 items). Instrument's content validation and semantic evaluation contributed to constructing and validating forms for analyzing occupational risks and adjusting respondents' language and sociocultural components.
\end{abstract}

Keywords: school food service; occupational risk; food handler; knowledge; attitude

\section{Introduction}

The school strongly influences the students' behavior, and when their environment is adequate, it is considered favorable for the formation and consolidation of healthy habits [1] The global strategy for feeding young children recommends that school menus promote healthy and adequate food to children and adolescents [2]. Thus, using varied, nutritious, and safe food is recommended to promote eating habits that contribute to students' growth and development and academic performance [3].

In Brazil, adequate food is a guaranteed right for students enrolled in public, philanthropic, and community organizations in partnership with the government through the National School Feeding Program (Programa Nacional de Aliemtação Escolar-PNAE). It is considered one of the largest, most comprehensive, and long-lasting programs in the area of school meals in the world [4] and involves the production and offering of meals at school. In this sense, school food services are essential in offering healthy and nutritious meals to Brazilian children [3,5,6]. 
Therefore, it reinforces that the foodservice segment plays an essential role in the health and well-being of the population through the quality of the produced food, influencing aspects of the economy and public health [7]. The production of meals is an aspect that requires special care as it is related to the risks of contamination (chemical, physical, and biological hazards) during food handling [8]. The lack of trained personnel regarding knowledge in food hygiene and food safety principles could affect the safety of the meals for the students. Thus, to ensure food safety in the preparation of meals, all stages of the production process must be well executed and controlled, from the acquisition and control of raw materials to the distribution of ready-to-eat meals [9].

Food service work is exhausting not only because of the intense pace of food production but also because of the conditions in which it is carried out: high temperature, presence of noise, humidity, activities with risk of injury, time pressure for delivery meals, not to mention small spaces, insufficient number of equipment, and inadequate structures of many establishments [8]. These working conditions can cause discomfort, fatigue, and even occupational accidents and illnesses [10]. It is generally assumed that the injuries incurred in the food sector are relatively inconsequential. However, several workers employed in these sectors are exposed to dangerous jobs [11]. Foodservice operations have accident and illness rates as high as industries commonly thought of as hazardous places to work, presenting many hazards that can result in accidents, injuries, and illnesses [11]. The risks related to workers' health can be physical, chemical, biological, ergonomic, and psychosocial. These risks can increase the possibility of work accidents, which can cause immediate or future/chronic injuries. Immediate injuries can cause a reduction in work capacity, while future injuries (occupational diseases) are acquired throughout a lifetime due to continued activity in the work environment [12].

In Brazil, the productive process of meals concerning workers' health lacks theoreticalmethodological investments to develop, test, and validate instruments and criteria capable of articulating constructs to the reality of schools managed by the National School Feeding Program (PNAE). Psychometrics provides several tools, strategies, and statistical analyses to validate instruments and constructs to minimize measurement errors. The development and validation of instruments may collaborate to investigate occupational risks in school food services (SFS). Occupational risk is a "combination of the probability of occurrence of hazardous events or exposures to work-related harmful agents and the severity of injuries and health problems that may be caused by the event or exposure" [13].

Considering that scholar workers are exposed to occupational risks [14,15] and school food handlers are responsible for the reception, storage, pre-preparation, preparation, and distribution of food in SFS [16], the validation of instruments will potentially contribute to the investigation of risks in SFS allowing the proposition of control measures related to occupational health. A risk map is a graphical representation of conglomerates of factors existing in the workplace, which are capable of causing damage to workers' health [17]. Among the factors, there are the spatial conditions of the work environment and forms of work organization.

In Brazil, SFS food handlers participate in all stages of the meal production process [18], which differs from non-school food service food handlers [19], which causes a work overload for them. It is necessary to scale the physical structure of the SFS and assess whether the equipment and utensils available for the production of meals meet the ergonomic criteria for the production of menus suggested by the Education Development Fund (FNDE) [20] and the specialization of the workforce. Furthermore, the productive process of school meals does not include the use of technological innovations to produce safe foods and, consequently, increases the number of activities performed by food handlers $[21,22]$. In this context, occupational health aims to adopt preventive measures, with adjustments to the work environment, to minimize or eliminate workers' exposure to occupational risks that threaten the integrity and well-being of employees [23]. A systematic review concluded that there is an association between precarious employment and occupational injuries [24]. The International Labor Organization (ILO) and WHO state that 
each year, there are 360 million non-fatal occupational accidents, representing $19 \%$ of the deaths worldwide [25]. In Brazil, despite the underreporting of accidents at work, in 2019, there was a formal record of 10,659 accidents involving foodservice workers, ranking sixth among registered work accidents [26]. In the U.S., the food services presented occupational injuries and illnesses requiring days away from work at a rate of about 7.8 per 100 full-time employees [27]. A report published in the Philippines in 2019 recorded 2959 work accidents in food service activities, representing $6.4 \%$ of work accidents recorded in the year [28]. Despite the difference in population numbers between countries and the lack of accurate information about work accidents in food services, it is notable that there are a large number of work accidents in the foodservice sector in Brazil, highlighting the importance of studies on foodservice occupational risks. Studies on work safety in food services are essential to minimize the risk of accidents and the spread of diseases [12]. Knowing the different types of risks that expose the worker's health and life allows finding strategies that help fight existing diseases [12]. In this sense, we aimed to develop an instrument to assess occupational risk in school food services. In addition, to perform its content validation and semantic evaluation, we consider the possible health problems of school food handlers and the importance of the quality of instruments in the assessment of these in public SFS and their relationship to the production of school meals following PNAE regulations.

\section{Materials and Methods}

This study is multi-purpose, methodological, and validating in nature, and it is nested within a broader, multilevel study called "Occupational Risk Analysis in School Food Service Units in the city of Salvador, Bahia". This study was carried out in stages (Figure 1), involving the development/adaptation of assessment instruments, application of content and semantic analysis techniques, and validation of the instruments.

\subsection{Instruments Development}

The development of the instruments proposed for investigating occupational risks considered previous studies and Brazilian legislation [29-31]. Instruments numbered 1 and 4 were built for application by the field research team, and instruments 2 and 3 were designed from the perspective of self-reporting by food handlers. The first instrument (Identification of socioeconomic and demographic conditions of food handlers and Characteristics of school functioning) consisted of 30 items. The characteristics of the schools were Local, Teaching modality, Operating shifts, SFS Management, Number of meals provided, Planned menu, Number and working hours of food handlers, and Food handlers' demographics (gender, age), labor (working hours), and qualification (training) [31]. After a pilot study in three municipal schools (not included in the primary study sample), other labor issues were included in the instrument (1) employment relationship with the Municipal Secretary of Education (public or contracted employee), function registered in the work, social security card, and training on occupational hygiene.

The second instrument sought to assess the "Level of knowledge and attitudes of food handlers about food hygiene" by self-reporting. It was adapted from the study by Ferreira et al. [31]. The instrument consisted of four blocks and 33 questions, which were assessed using a five-point Likert-type scale: (1) Totally disagree; (2) Partially disagree; (3) Neither agree nor disagree; (4) Partially agree; and (5) Totally agree. The characterization of the level of knowledge and attitudes considered the percentage of correct answers: $\geq 70 \%$ as "Satisfactory", between $50 \%$ and $69.9 \%$ "Satisfactory with Restriction", and "Unsatisfactory" when the percentage ranged from 0 to $49.9 \%$ [32]. 


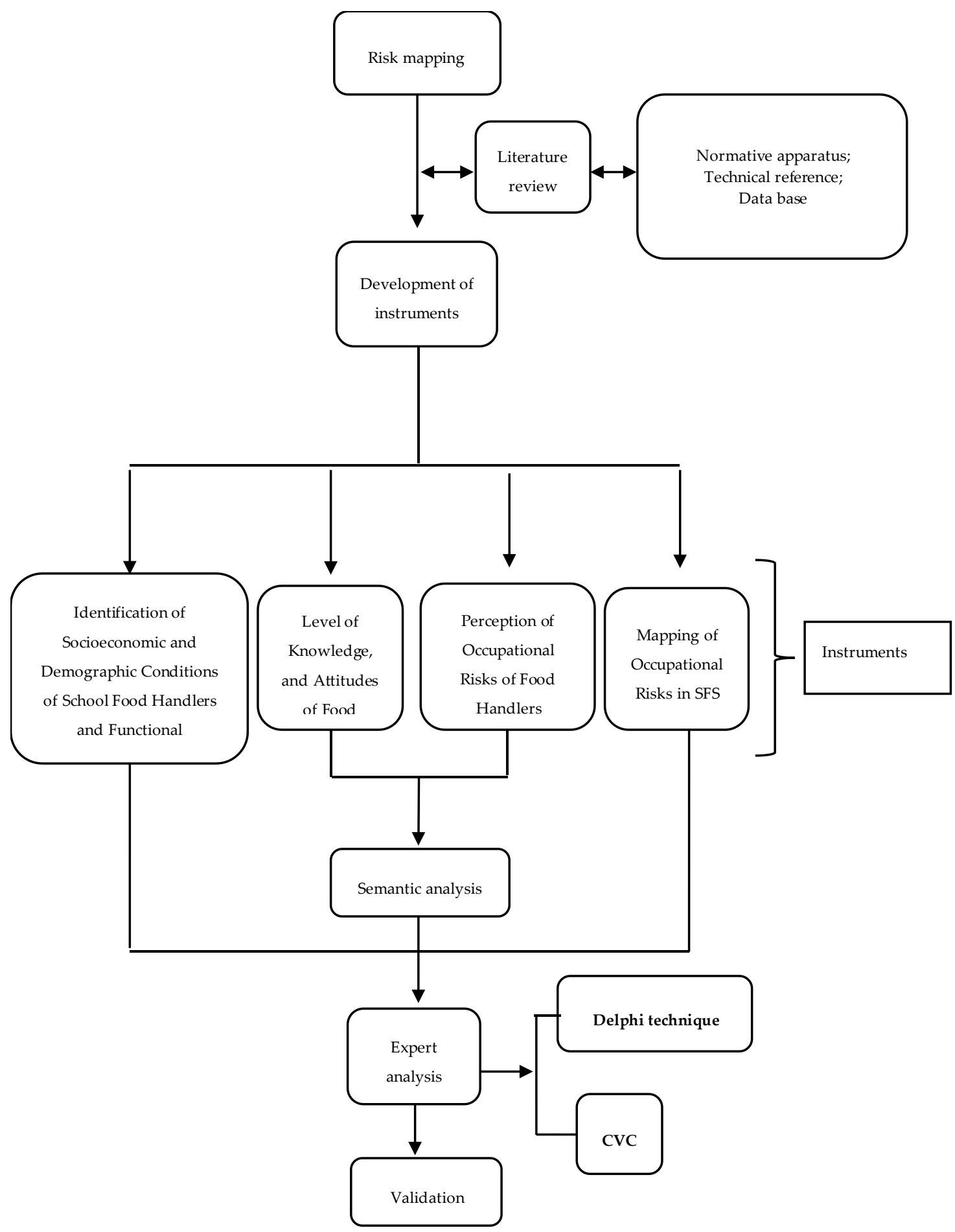

Figure 1. Flowchart of the construction and internal validation of instruments for assessing occupational health in school foodservice in Bahia/Brazil.

The "Perception of Occupational Risks by Food Handlers" (third instrument) was prepared with accessible language to the target population, having as a guideline the normative aspects contained in four Brazilian Regulatory Standards (NR): NR 5-Internal Accident Prevention Commission [33]; NR 6-Personal Protective Equipment (PPE) [34]; NR 09-Assessment and Control of Occupational Exposures to Physical, Chemical, and Biological Agents [35] and NR 17-Ergonomics [36]. The adaptation of the instrument also considered the characteristics of the SFS: areas for the production of food, equipment, daily production process, described in the Public Notice 01/2017 [37]. The handlers were asked 
to respond to the instrument using a five-point Likert-type scale: (1) Strongly disagree; (2) Partially disagree; (3) Neither agree nor disagree; (4) Partially agree; (5) Totally agree.

According to the score obtained by the food handler, the occupational risk perception scale suggested in this study was used: Very Low Perception (0 to 1.5); Low Perception (1.51 to 2.5); Regular Perception (2.51 to 3.5); High Perception (3.51 to 4.5); and Very High Perception (4.51 to 5).

The fourth instrument (Occupational Risk Mapping) also considered the recommendations of the NR mentioned above, in addition to the Technical Regulation of Good Practices for Food Services-RDC n ${ }^{\circ}$ 216/2004 [30]. It consisted of 97 items distributed into five topics: (a) Physical Risks—28 items; (b) Chemical Risks-12 items; (c) Biological Risks-13 items; (d) Ergonomic hazards-14 items; and (e) Mechanical hazards-30 items. A three-point scale was used: (1) Yes; (2) No; (3) Not applicable, based on Annex II of RDC n ${ }^{\circ} 275 / 2002$ [38]. For the classification of occupational risks, the cutoff point used by Stedefeldt et al. [29] was adapted when classifying health risks in SFS. Thus, for the classification of occupational risks, according to the compliance score obtained: very high occupational risk (0 to $25 \%$ ); high occupational risk (26 to $50 \%$ ); regular occupational risk (51 to $75 \%$ ); low occupational risk (76 to $90 \%$ ); and very low occupational risk (91 to $100 \%$ ).

\subsection{Instruments Experts' Evaluation}

After the instruments' development and/or adaptation, sixteen experts in food and nutrition were invited to participate in the experts' technique [39]. Inclusion criteria were having professional and/or academic practice of at least two years in the management of food service and/or school meals and/or work safety. There was prior contact with the experts by e-mail, sending an invitation letter, an informed consent form with the presentation of the study, methodology, and characteristics for instruments' validation. The experts received guidance to assess the instruments' content, clarity, and cohesion. It included: (a) assessment of each item's relevance to the question in the SFS; and (b) assessment of each item's relevance to the context experienced by the SFS food handlers. For each assertion, the experts could suggest the items' inclusion, change, or exclusion. The Delphi technique described the congruence between experts [39].

The Content Validity Coefficient (CVC) was used, with the item being accepted when it reached a CVC $\geq 0.80$ [40]. Calculations were performed according to the equation of Tilden et al. [41]:

$$
\text { Agreement }(\%)=\frac{\text { number of experts who gave grades } 4 \text { and } 5}{\text { total number of experts }} \times 100 \text {. }
$$

The CVC calculations comprised four steps: (1) Calculation of the average grades 4 and 5 of each item. According to the average, initial CVC (CVCi) was obtained; (2) Calculation of error (Pei) to remove possible biases between the experts; (3) Final CVC of each item (CVCc) calculated from the subtraction of CVCi by Pei; (4) Total CVC (CVCt) of the questionnaire for each of the characteristics (language clarity and practical relevance), subtracting the mean CVCi from the mean Pei (MPei).

Instrument 2, "Level of Knowledge and Attitudes of Food Handlers in School FNU", and 3, "Perception of Occupational Risks by Food Handlers", were adapted to the sociocultural repertoire of food handlers, using the focus group technique [42]. The sample consisted of seven food handlers who worked in municipal public schools, which were selected by convenience. The criteria used to select the components of the focus group were proximity of the municipal schools to the place where the group meetings would take place and the release of food handlers from work activities by school managers. Focus group discussions or panels are often used to explore a specific set of issues and allow users views on the quality of care [43], or in this case, the possibility of exploring differences in understanding the items assessed and the experiences and specialties of the workers for whom such instruments were intended. The assessment of the semantics of the instruments took place through content analysis [44]. 


\subsection{Semantic Analysis by the Focus Group}

The focus group was conducted in four weekly sessions with approximately $120 \mathrm{~min}$ each to adapt the instruments to the sociocultural repertoire. Each meeting had a central axis: first, PNAE: role and appreciation of food handlers; second, Foodborne illnesses (FBI): causes and symptoms; attitudes and work practices that pose a risk to the production of safe food for students and workers, limiting factors for adopting good hygiene practice (GHP)—physical structure, training, interpersonal relationships; and third, Occupational risks, the physical structure of school SFS, vector control and urban pests, factors related to the environment and time of preparation and distribution of school meals. The instruments were only presented in the fourth meeting, incorporating terms that emerged in the previous sessions. On that occasion, food handlers were motivated to read, discuss, and take a stand regarding the issues and report whether the instruments were easy to interpret. Consensus for each instrument item was obtained when $80 \%$ or more of the food handlers agreed with the assertion [40].

Focus group moderators used the dialogic research method to allow participants to interact with each other and with the moderators [42]. All dialogues between participants and moderators were recorded in all meetings with the due consent of the participants.

\subsection{Data Analysis}

The descriptive analysis of the Delphi Technique data took place in the Microsoft Excel for Windows 10 program. To analyze the permanence of each item, the final CVC was calculated. Items that received agreement $\geq 0.80$ remained in the instrument.

The content analysis technique was used to analyze the semantics of the focus group. If similar concepts were found among participants with $80 \%$ agreement, the item would not be changed; otherwise, the discussion of concepts between researchers and participants would continue. Each of the assertions was analyzed considering the assumptions pointed out by Bardin [45].

\subsection{Ethical Aspects}

The project Occupational Risk Analysis in School Food Services in Salvador, Bahia, Brazil was approved by the Research Ethics Committee of the School of Nutrition of the Federal University of Bahia under opinion $n^{\circ} 2.121 .882 / 2017$. Food handlers and specialists (experts) signed the Free and Informed Consent Term.

\section{Results}

\subsection{Preparation of Instruments and Content Evaluation by Experts}

Table 1 shows the stages of construction and validation of the instruments for the analysis of occupational health in SFS, and the instruments' results after the four stages of Delphi. The analysis of the final CVC identifies that the instruments obtained values above $90 \%$, as proposed by Alexandre and Coluci [40], who advocate CVC above $80 \%$.

In the first round of Delphi, there was a consensus among the experts for some items. The first instrument, "Identification of Socioeconomic and Demographic Characteristics of Food Handlers and School Functioning Characteristics" consisted of 30 items (Tables 1 and S1). The final instrument with its 30 items will be able to identify both the characteristics of the schools and the characteristics of the food handlers for later association with instruments that will assess the presence of occupational hazards in the SFS and the level of knowledge and attitudes of food handlers. 
Table 1. Construction and content validation of instruments for the analysis of occupational health in school food services.

\begin{tabular}{|c|c|c|c|c|c|c|c|c|}
\hline \multirow[b]{2}{*}{ Instrument } & \multirow[b]{2}{*}{ Items } & \multicolumn{7}{|c|}{ Experts' Evaluation } \\
\hline & & 1st Evaluation & $\% \mathrm{C}$ & $\stackrel{2^{\circ}}{\text { Evaluation }}$ & $\% \mathrm{C}$ & $\begin{array}{c}3^{\circ} \\
\text { Evaluation }\end{array}$ & $\% \mathrm{C}$ & $\begin{array}{l}\text { Means of Item } \\
\text { Concordancy } \\
(\%) / C V C\end{array}$ \\
\hline $\begin{array}{c}\text { (1) Identification of } \\
\text { Socioeconomic and } \\
\text { Demographic } \\
\text { Conditions of Food } \\
\text { Handlers and } \\
\text { Characteristics of } \\
\text { School Functioning } \\
\text { (Table S1) }\end{array}$ & 28 & $\begin{array}{l}26 \text { approved } \\
2 \text { modified } \\
2 \text { included }\end{array}$ & $\begin{array}{l}4 \text { items } \\
\leq 80 \%\end{array}$ & 4 items & $\geq 80 \%$ for all & - & - & $\begin{array}{l}100 \% \text { for } \\
30 \text { items } \\
(\mathrm{CVC}=1)\end{array}$ \\
\hline $\begin{array}{l}\text { (2) Level of Knowledge } \\
\text { and Attitudes of Food } \\
\text { Handlers (Table S2) }\end{array}$ & 35 & $\begin{array}{l}25 \text { approved } \\
6 \text { excluded } \\
4 \text { modified } \\
4 \text { included }\end{array}$ & 8 items $\leq 80 \%$ & 8 items & $\geq 80 \%$ for all & - & - & $\begin{array}{c}97.95 \% \text { for } \\
33 \text { items } \\
(\mathrm{CVC}=0.979)\end{array}$ \\
\hline $\begin{array}{l}\text { (3) Perception of } \\
\text { Occupational Risks } \\
\text { (Table S3) }\end{array}$ & 16 & $\begin{array}{l}4 \text { approved } \\
2 \text { excluded } \\
10 \text { modified } \\
2 \text { included }\end{array}$ & $\begin{array}{l}12 \text { items } \\
\leq 80 \%\end{array}$ & 12 items & $\geq 80 \%$ for all & - & - & $\begin{array}{l}90 \% \text { for } 16 \text { items } \\
(\mathrm{CVC}=0.90)\end{array}$ \\
\hline $\begin{array}{l}\text { (4) Mapping of } \\
\text { Occupational Risks } \\
\text { (Table S4) }\end{array}$ & 52 & $\begin{array}{l}28 \text { approved } \\
6 \text { excluded } \\
18 \text { modified } \\
51 \text { included }\end{array}$ & 69 items $\leq 80 \%$ & 69 items & $\begin{array}{c}\leq 80 \% \text { para } 33 \\
\text { items } \\
36 \text { items } \geq \\
80 \%\end{array}$ & 36 items & $\begin{array}{l}\geq 80 \% \text { for } \\
36 \text { items }\end{array}$ & $\begin{array}{l}95.42 \% \text { for } 97 \text { items } \\
\quad(\mathrm{CVC}=0.954)\end{array}$ \\
\hline
\end{tabular}

The second instrument was composed of two blocks: knowledge, with 14 items, and attitudes, with 19 items, totaling 33 items. Delphi was run in three rounds for this construct to reach a cutoff point $>80 \%$ (Tables S1 and S2).

The third instrument ended with 16 items (Tables S1 and S3). This instrument also required three rounds to reach $>80 \%$ consensus among experts.

The "Occupational Risk Mapping in SFS" instrument (Tables S1 and S4) was adjusted with three steps, and 51 items were included after submitting to the experts. Although long, it proved theoretically essential to analyze the congruence between knowledge and attitudes in food hygiene and risk perception, using objective criteria within Brazilian legislation [30,33-36]. The final instrument with 97 items and five factors was distributed as follows: (a) Physical Risks-28 items; (b) Chemical Risks-12 items; (c) Biological Risks-13 items; (d) Ergonomic hazards-14 items and Mechanical hazards-30 items.

\subsection{Experts Evaluation}

Sixteen experts were invited to participate in the content validation of items as judges. Figure 2 shows the adhesion of judges in each cycle of the Delphi technique.

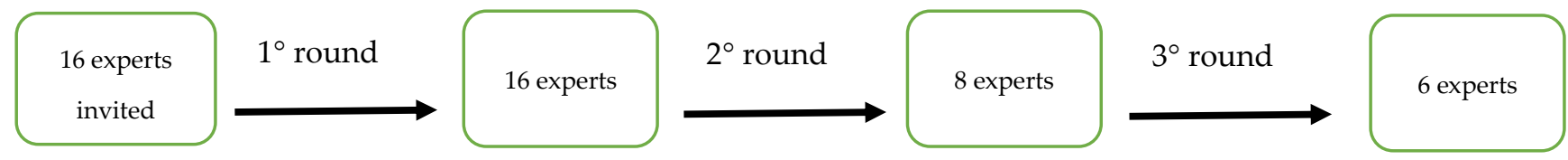

Figure 2. Flowchart of the number of experts participating in each round of the Delphi technique.

All judges responded to the first round. The percentage of experts adhesion from the first round to the second round was 50\% (8) and from the second to the third round was $75 \%$ (6). Items were judged according to the criteria of relevance, clarity, and consistency.

\subsection{Semantic Analysis by the Focus Group}

Seven food handlers from municipal public schools were invited to form the focus group, but six attended the four meetings, with $85.71 \%$ of the guests participating. All food handlers in the focus group were female, with a mean age of 41 years and meantime in the function of $>10$ years and a high school degree.

For the orientation of the focus group, two researchers participated in the roles of moderator and co-moderator [42]. The moderator had experience in school meals, man- 
agement of food services, and teaching. The co-moderator had experience in training and educational activities in municipal public schools with food handlers, teachers, and schoolchildren. As the objective was to identify whether the instruments' semantics met the food handlers' sociocultural repertoire, the researchers used the dialogic research method [42]. Thus, each item of the instruments was read and discussed with the food handlers and among them, investigating verbal expressions commonly used by the study's target audience.

In the first meeting, with the central axis, PNAE: role and valuation of food handlers, the researchers presented the study and directed the form "to whom it is intended" [45]. Subsequently, the food handlers reported their names, length of service, and why they worked in this SFS position. There was discussion about the importance of the PNAE for food and nutritional security of food handlers' activities.

In meetings 2 (Foodborne illness: causes and symptoms) and 3 (Occupational risks in SFS), the researchers identified that technical terms commonly used among nutritionists and other professionals in the food area were poorly understood by the food handlers. Among the words were "food poisoning", "safe food", names of microorganisms ("Salmonella sp.", "Shigella sp.", Clostridium botulinum), "occupational risk", and "food handler."

The food handlers questioned the moderators about the concepts and searched the sociocultural repertoire for other words that would allow for the clarity and cohesion of each item [45]. Thus, the words mentioned above were replaced by others: "Food poisoning" by "gastro-intestinal infection"; "Safe food" by "Food without contamination"; "Clostridium botulinum" for "Botulism"; "Food Handler" for "You", and "noise" for "fuss".

The inclusion of the words "I think" in the sentence attributed to food handlers the importance of their opinion while carrying out activities for food safety in the SFS. The word noise was replaced in the items by the word fuss, as it was associated with gnawing, wear of a package by rodents, while the word noise was associated with excessive noise and disturbance to hear. At the fourth meeting, the food handlers read and discussed the instruments with the researchers. There was an agreement regarding the number and content of the instruments' items by all participants.

This study has some limitations: Even though the items used in the survey were discussed and approved among experts, the survey itself lacks a reliability test (Cronbach's alpha that measures the internal consistency of the items used for each block). In future research, when the survey will be administered to respondents, based on the Cronbach's alpha coefficient, the survey might require modifications.

\section{Discussion}

Food service is represented by the food and nutrition activities carried out in services [46] including canteens, buffets, catering, bakeries, industrial kitchens, institutional kitchens, delicatessens, snack bars, bakeries, patisseries, restaurants, rotisseries, and similar. In this context, the SFS is included in this group and must offer meals with nutritional quality and safety characteristics following sanitary legislation [30] and the recommendations of the PNAE [47].

Most studies in the area of school feeding assess the sanitary conditions of the SFS and the adoption of good hygiene practices by food handlers [22,48]. The approach to occupational health in SFS still lacks studies that systematically assess, through validated instruments, exposure to occupational hazards. A study identified that $35 \%$ of food handlers in SFS in the city of São Paulo had some discomfort related to the presence of pain during the service, with legs being the most affected limbs [49]. The authors justified that the daily workday takes place in a standing posture and insufficient space for food production. It is important to identify that the school SFS produces a large number of meals and for the nutritional, sensory, and hygienic quality and safety to be considered, it is necessary to properly dimension the physical space, equipment, and food handlers.

Instrument validation must occur in two stages: instrument development based on a literature review and item analysis by experts with experience in the field $[39,50]$. In this 
study, the two stages were performed, with the inclusion and maintenance of items that had clarity and relevance to the concept of occupational health.

In the first instrument's Identification of Socioeconomic and Demographic Conditions of Food Handlers and School Functioning Characteristics', after the experts' analysis, the sociodemographic and labor items remained: gender, education, and time in the position and participation in periodic food hygiene training, respectively. These items will contribute to identifying the profile of food handlers in SFS and may be related to the adoption or not of good hygiene practices and the perception of occupational risks by these workers in SFS. The data gathering on the instrument "Functioning Characteristics of Schools" will identify the geographic location and management modality of SFS. Social segregation has repercussions on the environment, such as inequality itself, and the poorest strata of the population, with fewer resources, have fewer social achievements: among these achievements, access to schools of "lower quality" [51]. Consequently, these data may identify statistical significance between the geographic location related to spatial conditions and the adoption of good hygiene practices.

The instrument "Assessment of the Level of Knowledge and Attitudes in Food Hygiene" will identify if the food handlers recognize and have attitudes toward safe food production. The PNAE recommends that the foods offered meet the sanitary criteria for promoting health and preventing illnesses in schoolchildren [13]. A study identified a positive association between hand hygiene knowledge and food handlers' self-reported practices in SFS in Hulu Langa district, Malaysia [52]. According to the researchers, these results are related to ongoing education and supervision of food handlers by those responsible for implementing sanitary standards.

The study used the Likert-type scale, with five points to assess the level of knowledge and attitudes, which differs from other authors, who opted for the three-criteria scale $[31,53,54]$. Regarding the classification of the level of knowledge and attitudes, the studies by Ansari-Lari et al. [53] and Ferreira et al. [31] adopted a cutoff point equal to or greater than $70 \%$ for correct items so that the food handler could obtain a satisfactory classification. The authors rated smaller percentages as unsatisfactory. Studies that assess these aspects in food handlers in SFS are scarce, so we chose to expand the strata for the classification adopted by Araújo et al. [32] to know the aspects that could be improved in the study population.

The third instrument, "Perception of Occupational Risks of Food Handlers", was composed of items that will corroborate the assessment of the adoption of the recommendations of regulatory standards [33-36] in SFS through the perception of food handlers. The exhaustive work in the food service exposes workers to the requirement of high productivity, in a limited time, in inadequate working conditions related to the absence of equipment and inadequate dimensioning of areas $[55,56]$. A study showed that several inadequacies in working conditions are aggravated in the production of meals, starting with menu planning [57]. Often, inappropriate postures and the execution of monotonous and repetitive activities occurred due to inadequate planning of the menus. The constant lack or insufficiency of food and the malfunction of the equipment cause problems in the execution of the planned menu.

A study in Shiraz, Iran showed a high prevalence of injuries related to working with restaurant workers $(84 \%)$. The most common injuries were cuts and lacerations but also burns and falls. In this study, work experience was associated with the prevalence of occupational accidents [58]. In a study in a University restaurant in Rio de Janeiro (Brazil), with an average daily production of 2400 meals, workers reported a series of health problems that arise as a result of the demands of work [59]. Among them are high blood pressure, hearing loss, stress, nervousness, respiratory allergy, pain in the spine, legs, and hand joints; anxiety, sleep disorders; headaches, and fatigue. Chamma and Forastieri conducted a study evaluating cases of occupational accidents in restaurants in the city of São Paulo (Brazil) between 1988 and 1998 [60]. The authors found that 57.5\% of accidents occurred inside kitchens, with burns being more prevalent $(45.8 \%)$ followed 
by musculoskeletal injuries (40.6\%). The main causes were heat exposure, slippery floors, improper installations, and the environment (noise, intense heat, poor lighting, and high humidity) [60].

Regarding Work-Related Musculoskeletal Disorders, a study in Ethiopia evaluated 595 restaurant workers in Gondar city [61]. The authors evaluated musculoskeletal symptoms within the past 12 months; $90.42 \%$ (538) workers had job stress. Of the 595 workers interviewed, $81.5 \%$ reported pain or ache in any part of the neck, shoulder, upper back, lower back, wrist, elbow, hip/thigh, knee, and ankle [61]. The Ethiopian study is in agreement with other studies that also showed a high percentage of Work-Related Musculoskeletal Disorders: 84\% in Taiwan [62], 69.2\% in Spain [63], 59\% in Turkey [64], and 78\% in Bangladesh [65].

All these work conditions result in lower job satisfaction, fatigue, decreased productivity, health problems, and accidents. Depression or anxiety accounts for $51 \%$ of all work-related illnesses, according to the Health and Safety Executive report on Work-related stress, anxiety, or depression statistics in Great Britain [66].

The instrument "Occupational Risk Mapping in SFS" addresses aspects related to occupational hygiene. In food and nutrition services, such as the SFS, there are five occupational hazards: physical (lighting, temperature, noise); biological (presence of pathogens); chemical (contact with cleaning products, among others), ergonomic (standing posture, repeated movements, stress, time pressure) and accidents (falls, burns, cuts) [67]. Therefore, the Regulatory Standards propose strategies to identify and minimize and/or eliminate occupational hazards in work environments [33-36]. In this context, identifying the presence of risks in SFS may sensitize the PNAE's Executing Entities to adopt preventive measures to promote occupational health in the work environment.

The literature does not indicate a consensus regarding the adequate number of experts for content validation in the instruments validating. However, it suggests between six and twenty experts $[39,50]$. The procedure adopted in the study allowed the opinion of experts from different areas on the relevance and cohesion of the items that corroborate to identify aspects related to occupational health in SFS.

The focus group's semantic analysis of the instruments "Assessment of the Level of Knowledge and Attitudes in Food Hygiene and Perception of Occupational Risks "allowed adjustments in the wording of items to the sociocultural repertoire of food handlers at SFS [45]. It is noteworthy that the presence of females in activities related to food production is common [49]. Since these activities are similar to domestic work and in the school environment, the presence of women in food production is associated with maternal care with schoolchildren.

In the semantic analysis, words were substituted to allow food handlers' correct interpretation of items [45]. Among the replaced words was "handling", which was interpreted as excessive touching of any object, and "safety" was related to public safety and not the concept of safe food. All items judged by the expert remained in the instruments submitted to focus group analysis. However, the semantic change contributed to the interlocution of the instruments with the sociocultural repertoire of food handlers in the SFS [45].

\section{Conclusions}

The instruments were built and validated in terms of content and semantics to identify aspects related to occupational health in SFS and will be used to identify occupational risks and assess the level of knowledge and attitudes in food hygiene and the perception of occupational risks of food handlers. These instruments were semantically validated through focus groups and are more adequate to this type of workers' reality, since the level of education affects comprehension.

It will be possible to better comprehend the occupational risk that food handlers face in food services, since studies in this area are scarce. Food handlers are exposed to many 
occupational risks that can, in addition to affecting the quality of the work provided, reduce the employee's useful time in the food sector.

Supplementary Materials: The following supporting information can be downloaded at: https: / / www.mdpi.com/article/10.3390/su14031728/s1, Table S1. Identification of socioeconomic and demographic conditions of food handlers and characteristics of school functioning; Table S2. Level of knowledge and attitudes of food handlers about food hygiene; Table S3. Perception of occupational risks by food handlers; Table S4. Occupational risk mapping.

Author Contributions: Conceptualization, J.d.S.F., M.d.P.N.A., R.d.R.F.B. and R.d.C.C.d.A.A.; methodology, J.d.S.F., M.d.P.N.A., R.d.R.F.B. and R.d.C.C.d.A.A.; validation, J.d.S.F., M.d.P.N.A., R.d.R.F.B. and R.d.C.C.d.A.A.; formal analysis, J.d.S.F., M.d.P.N.A., R.d.R.F.B. and R.d.C.C.d.A.A.; investigation, J.d.S.F.; resources, R.B.A.B., R.d.C.C.d.A.A. and R.P.Z.; data curation, J.d.S.F. and R.d.C.C.d.A.A.; writing-original draft preparation, J.d.S.F., M.d.P.N.A., R.d.R.F.B., R.B.A.B., R.d.C.C.d.A.A. and R.P.Z.; writing一review and editing, R.B.A.B., R.d.C.C.d.A.A., R.P.Z. and A.R.; visualization, J.d.S.F., M.d.P.N.A., R.d.R.F.B., R.B.A.B., R.d.C.C.d.A.A., R.P.Z. and A.R.; supervision, R.d.C.C.d.A.A., A.R., H.H., A.A.-M. and L.A.-C.; project administration, A.R., R.d.C.C.d.A.A., H.H., A.A.-M. and L.A.-C. All authors have read and agreed to the published version of the manuscript.

Funding: This research received no external funding.

Institutional Review Board Statement: This study was approved by the Research Ethics Committee of the School of Nutrition of the Federal University of Bahia (protocol number 2.121.882/2017).

Informed Consent Statement: Informed consent was obtained from all subjects involved in the study.

Data Availability Statement: The study did not report any data.

Acknowledgments: National Council for Scientific and Technological Development (CNPq) for the support.

Conflicts of Interest: The authors declare no conflict of interest.

\section{References}

1. Martins Rodrigues, C.; Giordani Bastos, L.; Stangherlin Cantarelli, G.; Stedefeldt, E.; Thimoteo da Cunha, D.; Lúcia de Freitas Saccol, A. Sanitary, Nutritional, and Sustainable Quality in Food Services of Brazilian Early Childhood Education Schools. Child. Youth Serv. Rev. 2020, 113, 104920. [CrossRef]

2. FAO; WHO. Sustainable Healthy Diets-Guiding Principles; FAO: Rome, Italy; WHO: Geneva, Switzerland, 2019 ; p. 44.

3. WHO. Global Strategy for Infant and Young Child Feeding. In Fifthy-Fourth World Health Assembly; WHO: Geneva, Switzerland, 2001; p. 5.

4. Bicalho Alvarez, D.; Paulo, S.; Slater Villar, B. Efeito Da Lei Federal 11.947/09 Na Qualidade Nutricional Dos Cardápios Propostos Pelo Programa de Alimentação Escolar Do Estado de São Paulo. Master's Thesis, University of São Paulo, São Paulo, Brazil, 2017. Available online: https:/ / teses.usp.br/teses/disponiveis/6/6138/tde-01082017-143518/pt-br.php (accessed on 1 February 2022).

5. Gerritsen, S.; Dean, B.; Morton, S.M.B.; Wall, C.R. Do Childcare Menus Meet Nutrition Guidelines? Quantity, Variety and Quality of Food Provided in New Zealand Early Childhood Education Services. Aust. N. Z. J. Public Health 2017, 41, 345-351. [CrossRef] [PubMed]

6. Myers, G.; Sauzier, M.; Ferguson, A.; Pettigrew, S. Objective Assessment of Compliance with a State-Wide School Food-Service Policy via Menu Audits. Public Health Nutr. 2019, 22, 1696-1703. [CrossRef]

7. Silva Junior, E.A. Manual de Controle Higiênico-Sanitário Em Alimentos; Varela: São Paulo, Brazil, 2008.

8. Araújo, E.M.G.; Alevato, H.M.R. Abordagem Ergológica Da Organização e Das Condições de Trabalho Em Uma Unidade de Alimentação e Nutrição. Inovação Gestão e Produção 2001, 3, 10-22.

9. $\quad$ Barreto, L.K.S.; Leone, N.M.C.P.G.; Nascimento, L.C. Trabalho, Prazer e Sofrimento: Um Estudo Em Unidades Produtoras de Alimentação. Razón Y Palabra 2016, 20, 553-580.

10. Nepomuceno, M.M. Riscos Oferecidos à Saúde Dos Trabalhadores de Uma Unidade de Alimentação e Nutrição; Universidade de Brasília: Brasília, Brazil, 2004.

11. Michigan Department of Licensing and Regulatory Affairs Hazards in the Food \& Beverage Industry Brochure. Available online: https:/ / www.michigan.gov/documents/cis_wsh_cet0108_108504_7.htm (accessed on 25 January 2022).

12. Epifânio, M.A.B.; Rique, T.P.; Nascimento, S.M. Saúde e Sofrimento do Trabalhador Atuante em Restaurantes Universitários: Uma Breve Revisão/Health and Suffering of Workers in University Restaurants: A Brief Review. Braz. J. Dev. 2020, 6, 93678-93693. [CrossRef]

13. Brasil-Ministérios da Educação Brazil (Ministry of Health of Brazil). Resolução No 6, de 08 de Maio de 2020; Ministério da Saúde: Brasília, Brazil, 2020; p. 1. 
14. Diehl, L.; Marin, A.H. Adoecimento Mental em Professores Brasileiros: Revisão Sistemática da Literatura Mental Disorders In Brazilian Teachers: Systematic Review of Literature. Estudos Interdisciplinares em Psicologia 2016, 7, 64-85. [CrossRef]

15. Nunes Pimentel, B.; Fedosse, E.; da Graça Sartori Rodrigues, S.; Sérgio Cruz, K.; Alves Valentins, V.; Filha, S. Percepção Do Ruído, Saúde Auditiva e Qualidade de Vida de Professores de Escolas Públicas. Audiol. Commun. Res. 2016, 21, 1740-1741. [CrossRef]

16. Cristine Lopes Freitas Cardoso, K.; da Hora Silva, S.; de Lourdes Alves Formiga Gestão em Saúde Ambiental, M.; Lúcia Pereira de Jesus Ribeiro, A.; Fátima Oliveira Almeida, M.; Guarnieri da Silva, C. Exposição Ao Nível de Ruído Da Equipe Do Setor Da Merenda de Uma Escola Estadual Do Grande ABC/Exposure to the Noise Level of the Teaching Sector of the Stunning School of Grande ABC. Braz. Appl. Sci. Rev. 2020, 4, 1822-1827. [CrossRef]

17. Mattos, U.A.D.O.; Freitas, N.B.B. Mapa de Risco No Brasil: As Limitações Da Aplicabilidade de Um Modelo Operário. Cad. De Saúde Pública 1994, 10, 251-258. [CrossRef]

18. Brasil Manual de Apoio Para as Atividades Técnicas Do Nutricionista No Âmbito Do PNAE. Available online: https: //www.fnde.gov.br/index.php/programas/pnae/pnae-area-gestores/pnae-manuais-cartilhas/item/10493-manual-deapoio-para-as-atividades- $\mathrm{t} \% \mathrm{C3} \%$ A9cnicas-do-nutricionista-no-mbito-do-pnae (accessed on 17 December 2021).

19. Fideles, I.C.; de Cassia Coelho de Almeida Akutsu, R.; Costa, P.R.F.; Costa-Souza, J.; Botelho, R.B.A.; Zandonadi, R.P. Brazilian Community Restaurants' Low-Income Food Handlers: Association between the Nutritional Status and the Presence of NonCommunicable Chronic Diseases. Sustain. Switz. 2020, 12, 3467. [CrossRef]

20. FNDE; Ministério da Educação. Resolução $N^{\circ} 26$ de 17 de Junho de 2013. Dispõe sobre o atendimento da alimentação escolar aos alunos da educação básica no âmbito do Programa Nacional de Alimentação Escolar-PNAE. Diário Oficial da União 2013. Available online: https:/ / www.fnde.gov.br/acesso-a-informacao/institucional/legislacao/item/4620-resolu\%C3\%A7\%C3\%A3 o-cd-fnde-n\%C2\%BA-26,-de-17-de-junho-de-2013 (accessed on 1 February 2022).

21. da Silva Graça, C.; Barbosa, J.B.; de Souza, M.Z.; da Silveira Moreira, A.; de Mello Luvielmo, M.; de Las Mercedes Salas Mellado, M. Addition of Collagen to Gluten-Free Bread Made from Rice Flour. Braz. J. Food Technol. 2017, 20, e2016105. [CrossRef]

22. Soares, D.D.S.B.; Henriques, P.; Ferreira, D.M.; Dias, P.C.; Pereira, S.; Barbosa, R.M.S. Boas Práticas Em Unidades de Alimentação e Nutrição Escolares de Um Município Do Estado Do Rio de Janeiro-Brasil. Ciência Saúde Coletiva 2018, 23, 4077-4083. [CrossRef]

23. Lima, K.D.M.; Canela, K.G.D.S.; Teles, R.B.D.A.; Melo, D.E.B.; Belfort, L.R.M.; Martins, V.H.D.S. Management in Occupational Health: Importance of Accident Investigation and Work Incidents in Health Services/Gestao Na Saude Ocupacional: Importancia Da Investigacao de Acidentes e Incidentes de Trabalho Em Servicos de Saude. Rev. Bras. Med. Trab. 2017, 15, 276-284. [CrossRef]

24. Koranyi, I.; Jonsson, J.; Rönnblad, T.; Stockfelt, L.; Bodin, T. Precarious Employment and Occupational Accidents and Injuries-A Systematic Review. Scand. J. Work. Environ. Health 2018, 44, 341-350. [CrossRef]

25. WHO WHO/ILO Joint Estimates of the Work-Related Burden of Disease and Injury, 2000-2016: Global Monitoring Report. Available online: https://www.who.int/teams/environment-climate-change-and-health/monitoring/who-ilo-joint-estimates (accessed on 16 January 2022).

26. Centro de Estudos da Saúde do Trabalhador e Ecologia Humana Previdência Social Divulga as Últimas Estatísticas de Acidentes de Trabalho I Cesteh. Available online: http:/ / www.cesteh.ensp.fiocruz.br/noticias/previdencia-social-divulga-ultimas-estatisticasde-acidentes-de-trabalho (accessed on 25 January 2022).

27. U.S. Bureau of Labor Statistics. Injury and Illness Rates Higher in Special Food Services than in Broader Food Services Industry: The Economics Daily: U.S. Bureau of Labor Statistics. Available online: https://www.bls.gov/opub/ted/2019/injury-andillness-rates-higher-in-special-food-services-than-in-broader-food-services-industry.htm (accessed on 25 January 2022).

28. Philippine Statistics Authority. 2017/2018 Integrated Survey on Labor and Employment (ISLE); PSA Complex: Quezon, Philippines, 2019.

29. Stedefeldt, E.; da Cunha, D.T.; Silva Júnior, Ê.A.; da Silva, S.M.; de Oliveira, A.B.A. Instrumento de Avaliação Das Boas Práticas Em Unidades de Alimentação e Nutrição Escolar: Da Concepção à Validação. Ciência Saúde Coletiva 2013, 18, 947-953. [CrossRef]

30. Agência Nacional de Vigilância Sanitária -Brazil. Resolução RDC No 216, de 15 de Setembro de 2004; Resolução: Brasília, Brazil, 2004; pp. 1-14.

31. Ferreira, J.D.S.; Cerqueira, E.S.; Carvalho, J.S.; Oliveira, L.C.; Costa, W.L.R.; Almeida, R.C.D.C. Conhecimento, Atitudes e Práticas Em Segurança Alimentar de Manipuladores de Alimentos Em Hospitais Públicos de Salvador, Bahia. Rev. baiana saúde pública 2013, 37, 35-55. [CrossRef]

32. De Araújo, T.G.; Botelho, R.B.A.; Akutsu, R.D.C.C.A.; Araújo, W.M.C. Conformity of Food Service Units with Legislation. J. Culin. Sci. Technol. 2016, 14, 75-89. [CrossRef]

33. Ministério do trabalho e Previdência -Brasil. Norma Regulamentadora No. 5-Comissão Interna de Prevenção de Acidentes; Ministério do trabalho e Previdência: Brasília, Brazil, 2021; pp. 1-33.

34. Ministério do trabalho e Previdência —Brasil. Norma Regulamentadora No. 6 (NR-6); Ministério do trabalho e Previdência: Brasília, Brazil, 2020; p. 1.

35. Ministério do trabalho e Previdência —-Brasil. Norma Regulamentadora No. 9 (NR-9); Ministério do trabalho e Previdência: Brasília, Brazil, 2020; p. 1.

36. Ministério do trabalho e Previdência-Brasil. Norma Regulamentadora No. 17 (NR-17); Ministério do trabalho e Previdência: Brasília, Brazil, 2020; p. 1.

37. Secretaria Municipal de Educação Pregão Eletrônico Edital 01/2017. Available online: http://www.licitacoes-e.com.br (accessed on 9 December 2021). 
38. Ministério da Agricultura, Pecuária e Abastecimento-Brasil. Resolução RDC No. 275; Ministério da Agricultura, Pecuária e Abastecimento: Brasília, Brazil, 2002; pp. 1-23.

39. Sinha, I.P.; Smyth, R.L.; Williamson, P.R. Using the Delphi Technique to Determine Which Outcomes to Measure in Clinical Trials: Recommendations for the Future Based on a Systematic Review of Existing Studies. PLoS Med. 2011, 8, e1000393. [CrossRef]

40. Alexandre, N.M.C.; Coluci, M.Z.O. Validade de Conteúdo Nos Processos de Construção e Adaptação de Instrumentos de Medidas. Ciência Saúde Coletiva 2011, 16, 3061-3068. [CrossRef]

41. Tilden, V.P.; Nelson, C.A.; May, B.A. Use of Qualitative Methods to Enhance Content Validity. Nurs. Reseach 1990, 39, $172-175$. [CrossRef]

42. Barbour, R. Grupos Focais; Artmed: Porto Alegre, Brazil, 2009; Volume 1.

43. Kitzinger, J. The Methodology of Focus Groups: The Importance of Interaction between Research Participants. Sociol. Health Illn. 1994, 16, 103-121. [CrossRef]

44. Bardin, L. Análise de Conteúdo; Edições 70: São Paulo, Brazil, 2011.

45. Bardin, L.; Reto, L.A. Análise de Conteúdo; Edições 70: São Paulo, Brazil, 2016; Volume 6, ISBN 9788562938047.

46. CFN (Conselho Federal de Nutricionistas) RESOLUÇÃO CFN No 600, DE 25 DE FEVEREIRO DE 2018. Available online: https:/ / www.cfn.org.br/wp-content/uploads/resolucoes/Res_600_2018.htm (accessed on 9 December 2021).

47. FNDE. Fundo nacional de desenvolvimento da educação Caderno de Legislação-PNAE/2019—Portal Do FNDE. Available online: https:/ / www.fnde.gov.br/index.php?option=com_k2\&view=itemlist\&layout=category\&task=category\&id=333 (accessed on 1 February 2022).

48. Da Silva, L.M.; Brasil, C.C.B.; Silveira, J.T.; de Moura, F.A.; Marques, A.Y.C.; Martini, C.S.; Schiavo, M.B. Avaliação Das Condições Higiênicas de Escolas de Ensino Infantil e Fundamental Por Meio Da Aplicação de Listas de Verificação. Segurança Aliment. E Nutr. 2016, 23, 837-848. [CrossRef]

49. Sandoval, L.C.N.; Spinelli, M.G.N. Ergonomic Conditions of School Food and Nutrition Units under the Same Management. Nutrivisa 2017, 3, 155-161. [CrossRef]

50. Smarandache, F.; Ricardo, J.E.; Caballero, E.G.; Vázquez, M.Y.L.; Hernández, N.B. Delphi Method for Evaluating Scientific Research Proposals in a Neutrosophic Environment. Neutrosophic Sets Syst. 2020, 34, 204-213. [CrossRef]

51. Colussi, C.F.; Pereira, K.G. Territorialização Como Instrumento Do Planejamento Local Na Atenção Básica, 1st ed.; Universidade de Santa Catarina: Florianópolis, Brazil, 2016; Volume 1.

52. Tan, S.L.; Bakar, F.A.; Abdul Karim, M.S.; Lee, H.Y.; Mahyudin, N.A. Hand Hygiene Knowledge, Attitudes and Practices among Food Handlers at Primary Schools in Hulu Langat District, Selangor (Malaysia). Food Control 2013, 34, 428-435. [CrossRef]

53. Ansari-Lari, M.; Soodbakhsh, S.; Lakzadeh, L. Knowledge, Attitudes and Practices of Workers on Food Hygienic Practices in Meat Processing Plants in Fars, Iran. Food Control 2010, 21, 260-263. [CrossRef]

54. Pagotto, H.Z.; Gonçalves Espíndula, L.; Gomes Da Vitória, A.; Clara De Moraes, M.; Machado, M.; Freitas Brilhante De São José, J.; Freitas, J.; De, B.; José, S. Nível De Conhecimento, Atitudes E Práticas Dos Manipuladores De Alimentos Em Serviços De Alimentação. DEMETRA Aliment. Nutr. Saúde 2018, 13, 293-305. [CrossRef]

55. Ferro, L.L.; Fialho, C.J.; Pires, C.R.F.; Teles, N.D.B.; Santos, V.F. Dos Condições Higiênico Sanitárias de Unidades de Alimentação e Nutrição de Escolas Públicas Do Estado Do Tocantins. Segurança Alimentar e Nutricional 2018, 25, 118-130. [CrossRef]

56. Vanez, C.; Vila, D.; Silveira, J.T.; Almeida, L.C. Condições Higiênico-Sanitárias de Cozinhas de Escolas Públicas de Itaqui, Rio Grande Do Sul, Brasil. Vigil. Sanit. Em Debate 2014, 2, 67-74. [CrossRef]

57. Novelletto, D.L.; Proença, R.P.C. O Planejamento Do Cardápio Pode Interferir Nas Condições de Trabalho Em Uma Unidade de Alimentação e Nutrição? Available online: https:/ / www.nutricaoempauta.com.br/lista_artigo.php?cod=105 (accessed on 25 January 2022).

58. Jahangiri, M.; Eskandari, F.; Karimi, N.; Hasanipour, S.; Shakerian, M.; Zare, A. Self-Reported, Work-Related Injuries and Illnesses Among Restaurant Workers in Shiraz City, South of Iran. Ann. Glob. Health 2019, 85, 68. [CrossRef]

59. Colares, L.G.T.; de Freitas, C.M. Work Process and Workers' Health in a Food and Nutrition Unit: Prescribed versus Actual Work Cad. De Saude Publica 2007, 23, 3011-3020. [CrossRef]

60. Chamma, L.; Forasteri, N. Análise Ergonômica de Acidentes de Trabalho e Doenças Ocupacionais Em Restaurantes, Ao Longo de Dez Anos. In Proceedings of the Anais do XV Congresso Mundial sobre Segurança no Trabalho, São Paulo, Brazil, 12-16 April 1999; p. 1.

61. Tegenu, H.; Gebrehiwot, M.; Azanaw, J.; Akalu, T.Y. Self-Reported Work-Related Musculoskeletal Disorders and Associated Factors among Restaurant Workers in Gondar City, Northwest Ethiopia, 2020. J. Environ. Public Health 2021, $2021,6082506$. [CrossRef]

62. Chyuan, J.Y.A.; Du, C.L.; Yeh, W.Y.; Li, C.Y. Musculoskeletal Disorders in Hotel Restaurant Workers. Occup. Med. 2004, 54, 55-57. [CrossRef]

63. European Agency of Safety Work. Inventory of Socio-Economic Information about Work-Related Musculoskeletal Disorders in the Member States of the European Union. Available online: https: / / osha.europa.eu/en/publications/factsheet-9-inventorysocio-economic-information-about-work-related-musculoskeletal (accessed on 26 January 2022).

64. Ilban, M.O. Musculoskeletal Disorders among First Class Restaurant Workers in Turkey. J. Foodserv. Bus. Res. 2013, 16, 95-100. [CrossRef] 
65. Yesmin, K. Prevalence of Common Work Related Musculoskeletal Disorders among the Restaurant Workers. Ph.D. Thesis, Department of Physiotherapy, Bangladesh Health Professions Institute, CRP, Dhaka, Bangladesh, 2013. Available online: http:/ /library. crp-bangladesh.org:8080/xmlui/bitstream/handle/123456789/61/Khaleda_Yesmin_1017.pdf?sequence=1\&isAllowed=y (accessed on 29 January 2022).

66. Health and Safety Executive-HSE. Work-Related Stress, Anxiety or Depression Statistics in Great Britain, 2021. 2021. Available online: https: / www.hse.gov.uk/statistics/causdis/stress.pdf (accessed on 29 January 2022).

67. de Paula, C.M.D. Riscos Ocupacionais e Condições de Trabalho Em Cozinhas Industriais; UFRGS: Porto Alegre, Brazil, 2011; Available online: https:/ / www.lume.ufrgs.br/handle/10183/65920 (accessed on 29 January 2022). 